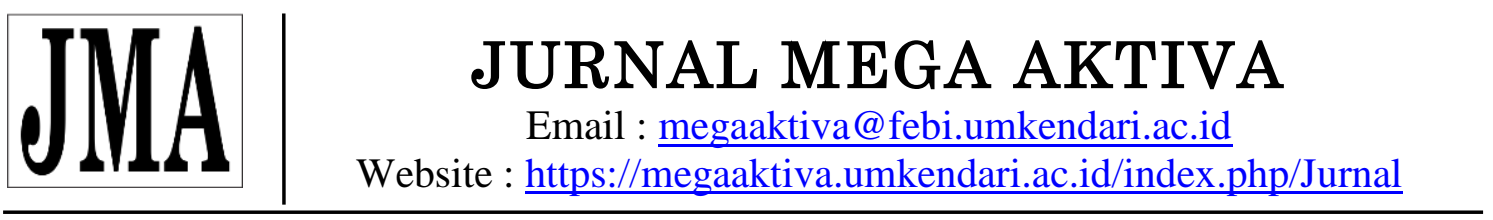

\title{
PENGARUH MOTIVASI KERJA TERHADAP KINERJA PEGAWAI PADA KANTOR BADAN PENELITIAN DAN PENGEMBANGAN PROVINSI SULAWESI TENGGARA
}

\author{
${ }^{1}$ Zulkifli \\ ${ }^{1}$ Dosen Fakultas Ekonomi dan Bisnis Islam, Universitas Muhammadiyah Kendari
}

\begin{abstract}
ABSTRAK
Penelitian ini bertujuan untuk mendeskripsikan dan mengetahui pengaruh motivasi kerja terhadap kinerja pegawai pada kantor Badan Penelitian dan Pengembangan Provinsi Sulawesi Tenggara. Populasi dalam penelitian ini adalah seluruh pegawai pada kantor Badan Penelitian dan Pengembangan Provinsi Sulawesi tenggara yaitu sebanyak 53 orang sekaligus sebagai responden penelitian (Metode Sensus). Pengumpulan data dilakukan dengan menggunakan kuesioner. Analisis data menggunakan analisis regresi linear sederhana. Hasil penelitian menunjukan bahwa motivasi kerja berpengaruh signifikan terhadap kinerja kinerja pegawai pada kantor Badan Penelitian dan Pengembangan Provinsi Sulawesi tenggara. Besarnya pengaruh motivasi kerja terhadap kinerja pegawai dapat dilihat dari nilai koefisien determinasi $\left(\mathrm{r}^{2}\right)=0,885$ atau 88,50\% yang berarti bahwa kinerja pegawai pada kantor Badan Penelitian dan Pengembangan Provinsi Sulawesi Tenggara 88,50\% ditentukan motivasi Kerja dan sisanya 11,50\% ditentukan oleh variabel lain atau diluar model peneltian.
\end{abstract}

Kata Kunci : Motivasi Kerja, Kinerja Pegawai

\section{ABSTRACT}

This study aims to determine the Effect of motivation on the performance of employees at the Badan Penelitian dan Pengembangan Provinsi Sulawesi Tenggara. The population in this study is all employees in the office Badan Penelitian dan Pengembangan Provinsi Sulawesi Tenggara as many as 53 people at the same times as respondents ( census method). Data collected by using Questionnaires. Data analysis using simple linear regression analysis. The study showed that the motivation significantly influence the performance of employees at the Badan Penelitian danPengembangan Provinsi Sulawesi Tenggara. The magnitude of the effect of work motivation on employee performance it can be seen from the coefficient of determination $\left(r^{2}\right)=0,885$ at 88,50\% which means that the performance of employees at the office Badan Penelitian dan Pengembangan Provinsi Sulawesi Tenggara 88,50\% determined by motivation and the rest 11, $50 \%$ determined by other variables or beyond the research model.

Keywords : Motivation, Employee Performance

\section{PENDAHULUAN}

Motivasi sangat relevan dan mempunyai hubungan antar manusia, khususnya antara atasan dan bawahan. Motivasi mempersoalkan bagaimana cara memotivasi gairah kerja bawahan, agar mereka mau bekerja keras dengan memberikan semua kemampuan dan 
keterampilannya untuk mewujudkan tujuan organisasi. Motivasi merupakan faktor yang mengarahkan dan mendorong perilaku serta keinginan seorang pegawai untuk melakukan suatu kegiatan, yang dinyatakan dalam bentuk usaha yang keras dan lemah. Hasibuan (2009).

Siagian (2004), mendefinisikan motivasi sebagai keseluruhan proses pemberian motif kerja kepada para bawahan sedemikian rupa sehingga mereka mau bekerja dengan ikhlas demi tercapainya tujuan organisasi dengan efekti dan efisien. Motivasi juga merupakan salah satu faktor yang mempengaruhi kinerja pegawai karena motivasi merupakan potensi yang perlu dikembangkan. Seseorang belum tentu dapat mengarahkan seluruh potensi yang dimilikinya untuk mencapai hasil yang optimal, sehingga masih diperlukan adanya pendorong agar mau menggunakan seluruh potensi yang dimiliki. Melihat kenyataan tersebut, sudah saatnya pimpinan dapat lebih memberikan kesempatan kepada pegawai agar dapat mengembangkan potensi diri agar lebih berprestasi.

Motivasi pegawai dipandang sebagai suatu hal yang sangat penting dalam rangka pengembangan organisasi, mengingat setiap individu dalam organisasi memiliki watak, kepribadian, cita-cita, keinginan dan harapan, secara kebutuhan yang relatif berbedabeda antara satu dengan yang lain. Oleh karena itu diperlukan adanya motivasi yang sangat kuat yang lahir dari dalam diri setiap individu dalam organisasi, dimana motivasi tersebut kemudian diwujudkan melalui sikap dan perilaku untuk melaksanakan tugastugasnya dengan baik sesuai dengan apa yang diharapkan dalam tujuan organisasi

Kinerja pegawai pada dasarnya mencakup sikap mental dan perilaku yang selalu mempunyai pandangan bahwa pekerjaan yang dilaksanakan ini harus lebih berkualitas ketimbang pelaksanaan pekerjaan dimasa lalu, untuk saat ini harus lebih berkualitas dari pada pekerjaan di masa lalu. Seorang pegawai akan merasa punya kebanggaan dan kepuasan tersendiri dengan kinerja yang telah dicapai. Kinerja yang baik merupakan keadaan yang di inginkan dalam kehidupan kerjannya. Apabila kinerja individu atau pegawai baik, maka diharapkan kinerja organisasi akan lebih baik pula. Hasibuan (2009).

Badan Penelitian dan Pengembangan Provinsi Sulawesi Tenggara yang bertugas membantu gubernur dalam menjalankan pemerintahan di bidang penelitian dan pengembangan yang didalamnya terdapat 53 orang pegawai dengan status 35 orang PNS dan 17 orang lainnya adalah pegawai Harian tetap. Sesuai hasil penelitian yang penulis lakukan didapatkan informasi bahwa kinerja pegawai pada instansi tersebut belum sepenuhnya sesuai dengan yang diharapkan bila ditinjau dari prestasi kerja, keahlian, perilaku, dan kepemimpinan. Pada aspek prestasi kerja antara lain terlihat bahwa masih terdapat pegawai yang harus diperintah dalam menyelesaikan tugas yang menjadi kewajibannya, bekerja tidak tepat waktu yang ditandai dengan terlambat masuk kantor, pulang sebelum waktunya. Selanjutnya pada keahlian antara lain terlihat bahwa ada pegawai yang tidak mempunyai keahlian untuk mengoperasikan Komputer. Pada aspek Perilaku antara lain terlihat pada saat jam kantor sedang berlangsung terlihat tidak bekerja waktu kerja banyak digunakan untuk mengobrol dengan teman hal yang tidak penting dan tidak ada kaintannya dengan pekerjaan, adanya pegawai yang tidak bisa membedakan jam kerja dan urusan pribadi. Pada aspek Kepemempinan Kurangnya dorong kerja dari atasan.

Badan Penelitian dan Pengembangan Provinsi Sulawesi Tenggara sebagai salah satu organisasi satuan perangkat daerah lingkup pemerintah Provinsi Sulawesi Tenggara yang bertugas membantu gubernur dalam menjalankan pemerintahan di bidang penelitian dan 
pengembangan, sehingga tugas pokok dan fungsi pegawai lingkup Badan Penelitian dan pengembangan serta aktivitas rutin dan memberikan izin penelitian. Oleh karena itu, pegawai harus dapat memiliki peran yang baik dalam menunjang kegiatan Badan Penelitian dan Pengembangan. Untuk melaksanakan tugas-tugas tersebut, pegawai dipimpin oleh atasan yang dapat memberikan motivasi kerja yang baik, bagaimana mengetahui motivasi kerja terhadap kinerja pegawai pada kantor Badan Penelitian dan Pengembangan Provinsi Sulawesi Tenggara.

\section{KAJIAN TEORITIS}

\section{Teori Motivasi}

Pendapat tentang teori motivasi menunjukkan bahwa motivasi timbul karena adanya suatu kebutuhan yang harus dipenuhi. Sehubungan dengan kebutuhan ini ada tiga teori yang dikemukakan, yaitu :

1. Teori Hirarki

Teori Hirarki sebagaimana yang dikemukakan oleh Maslow, dimana ia membagi kebutuhan manusia kedalam 5 tingkatan yakni :

a. Kebutuhan fisiologis, yaitu kebutuhan makanan, minuman, tempat tinggal dan sembuh dari sakit.

b. Kebutuhan keamanan dan keselamatan, yaitu kemerdekaan dari ancaman,keamanan dari lingkungan yang mengancam.

c. Kebutuhan rasa memiliki, social dan kasih sayang yaitu kebutuhan atas persahabatan, berkelompok, interaksi, dan kasih sayang.

d. Kebutuhan penghargaan, yaitu kebutuhan akan harga diri dan penghargaan dari pihak lain.

e. Kebutuhan aktualisasi diri yaitu kebutuhan untuk memenuhi diri seseorang dengan cara memaksimumkan penggunaan kemampuan, keahlian, dan potensi.Gibson (1996: 191-192).

2. Teori ERG

Teori ini dikemukakan oleh Alderfer, bahwa kebutuhan manusia terdiri atas tiga kategori yaitu existence (E) atau eksistensi, relatedness $(\mathrm{R})$ atau berkaitan, dan growth (G) atau kebutuhan pertumbuhan. Eksistensi meliputi kebutuhan fisiologi seperti rasa lapar, rasa haus, dan seks. Juga kebutuhan materi seperti gaji dan lingkungan kerja yang menyenangkan. Kebutuhan akan berkaitan, menyangkut hubungan dengan orang-orang yang penting bagi kita seperti : anggota keluarga, sahabat dan penyelia di tempat kerja. Kebutuhan akan pertumbuhan meliputi keinginan kita untuk produktif dan kreatif dengan mengarahkan segenap kesanggupan kita. Alderfer menyatakan bahwa bila kebutuhan akan eksistensi tidak terpenuhi, pengaruhnya kuat dalam keputusan. Misalnya, anda boleh menerima gaji yang cukup besar dan pekerjaan yang aman namun terus menginginkan peningkatan, meskipun kebutuhan akan eksistensi tampaknya sudah terpenuhi boleh jadi terus berlangsung menjadi motivator. Sebaliknya, kebutuhan akan berkaitan dan pertumbuhan boleh jadi meningkat ketika terpenuhi Pace( 2003).

3. Teori dua faktor (two factor theory of work motivation)

Teori ini dikemukakan oleh Herzberg dalam Pace (2003) yang mencoba menentukan faktor-faktor yang mempengaruhi motivasi dalam organisasi. Herzberg menentukan dua perangkat kegiatan yang memuaskan kebutuhan manusia, yaitu : (1) kebutuhan yang 
berkaitan dengan kepuasan kerja dan (2) kebutuhan yang berkaitan dengan ketidak puasan kerja. Faktor -faktor yang mempengaruhi kepuasan kerja disebut motivator, meliputi prestasi, penghargaan, tanggung jawab, kemajuan atau promosi, pekerjaan itu sendiri dan potensi bagi pertumbuhan pribadi. Semua ini berkaitan dengan pekerjaan itu sendiri. Bila faktor-faktor ini ditanggapi secara positif, pegawai cenderung merasa puas dan termotivasi. Namun, bila faktor-faktor tersebut tidak ada ditempat kerja, pegawai akan kekurangan motivasi namun tidak berarti tidak puas dengan pekerjaan mereka. Faktorfaktor yang berkaitan dengan ketidakpuasan disebut faktor-faktor pemeliharaan ( maintenance), meliputi : gaji, pengawasan, keamanan kerja, kondisi kerja, administrasi, kebijakan organisasi, dan hubungan antar pribadi dengan rekan kerja, atasan, bawahan di tempat kerja. Faktor- faktor ini berkaitan dengan lingkungan atau konteks pekerjaan itu sendiri. Itulah sebabnya mengapa program-program untuk memotivasi pegawai menggunakan sestem Herzberg menyebutnya motivasi melalui pekerjaan itu sendiri. Bila faktor-faktor ini ditanggapi secara positif, pegawai mengalami kepuasan atau tampak bermotivasi. Namun, bila faktor-faktor tersebut tidak ada, pegawai akan merasa tidak puas atau tidak termotivasi.

\section{Konsep Motivasi Kerja}

Setiyadi (2003) mengemukakan bahwa motivasi kerja merupakan kunci keberhasilan dalam suatu organisasi kerena efektif dan optimalnya kegiatan-kegiatan yang dilakukan akan ditentukan oleh ada atau tidak adanya motivasi kerja untuk mewujudkannya. Inti motivasi kerja adalah adanya pendorongan semangat kerja dan penjurusan aktivitas pegawai agar mampu mewujudkan maksud yang dikehendaki oleh organisasi. Pendapat tersebut menunjukkan bahwa motivasi kerja merupakan salah satu faktor penentu keberhasilan organisasi kerena motivasi merupakan semangat untuk bekerja optimal dalam rangka pencapaian tujuan organisasi.

Selanjutnya Maris (2007) mengemukakan bahwa motivasi kerja merupakan fungsi yang melekat baik pada pimpinan maupun bagi pelaksanaan operasional organisasi yang saling mempengaruhi dalam proses pelaksanaan kegiatan. Berdasarkan pandangan ini, maka motivasi kerja akan terwujud jika terdapat keterpaduan dan kerja sama yang baik antara pimpinan dengan bawahan. Keserasian dan keharmonisan hubungan antara pimpinan dan bawahan tersebut harus dipertahankan mengingat hal itu membawa pengaruh psikologi secara langsung terhadap bawahan, dalam arti bahwa apabila hubungan itu senantiasa terjalin dengan baik maka karyawan akan memiliki semangat kerja.

Selain itu pentingnya motivasi kerja dikemukakan pula oleh Syamsi (2003) bahwa salah satu aspek yang penting dalam mempertahankan dan menjamin kinerja adalah bagaimana kemampuan pimpinan dalam mempertahankan dan menjamin motivasi kerja melalui pemenuhan kebutuhan pegawai. Dalam hal ini, terdapat dua jenis kebutuhan yang perlu dijamin keseimbangannya, yaitu :

1. Kebutuhan material, adalah kebutuhan yang menyangkut kesejahteraan karyawan, yang meliputi gaji yang cukup, insentif, bonus dan lain-lain.

2. Kebutuhan non material, adalah kebutuhan fisikologis yang meliputi terjaminnya rasa aman dan kenyamanan kerja, adanya pengakuan atas prestasi yang dicapai, penghargaan, kenaikan pangkat, dan adanya kepercayaan. 
Pandangan tersebut didukung oleh setiawan (2000) yang mengemukakan bahwa dari kedua jenis kebutuhan maka kebutuhan materil merupakan faktor yang paling dominan mempengaruhi motivasi kerja, walaupun pendapat ini tidak selamanya tepat. Oleh karena itu, kompensasi akan menjadi motivasi orang untuk bekerja. Kebijakan kompensasi harus mempertimbangkan unsur-unsur seperti : (1) kebutuhan hidup minimum, (2) terjaminnya masa depan pekerja, (3) dinamika organisasi.

Susilo (2001) mengemukakan bahwa motivasi merupakan bagian integral dari manajemen dalam rangka melaksanakan tugas yang menjadi tanggung jawabnya sesuai ketentuan, aturan dan kebijakan organisasi. Dari pandangan diatas, terlihat bahwa motivasi dalam suatu proses kerja menduduki peranan penting dalam upaya mewujudkan tujuan organisasi secara efisien, efektif dan optimal.

\section{Indikator Motivasi Kerja}

Hasibuan (2009) mengemukakan bahwa motivasi kerja memiliki beberapa determinan penting yaitu : motif, harapan dan insentif. Lebih jelasnya diuraikan sebagai berikut :

1. Motif

Motif adalah suatu perangsang keinginan dan daya penggerak tertentu yang ingin dicapai . motif adalah daya atau kekuatan yang ada dalam diri ((inner potesial) seseorang. Motif adalah segala daya yang mendororng seseorang untuk melakukan sesuatu. Daya inilah yang mengarahkan dan mempertahankan perilaku orang dalam melaksanakan aktivitas tertentu. Motif merupakan daya penggerak dari dalam individu untuk melakukan aktivitas-aktivitas tertentu demi mencapai suatu tujuan. Dapat dikatakan bahwa motivasi seseorang tergantung pada kekuatan motif. Motif ini yang menyebabkan mengapa seseorang berusaha mencapai tujuan-tujuan, baik sadar maupun tidak sadar. Motif ini pula yang menyebabkan seseorang melakukan sesuatu yang dapat mengedalikan dan memelihara kegiatan-kegiatan, dan yang menetapkan arah umum yang harus ditempuh oleh seseorang tersebut. Motif dalam konteks penelitian ini diwujudkan dalam bentuk pemberian rangsangan untuk meningkatkan keinginan seseorang dan menjadi daya penggerak agar seseorang bekerja secara maksimal untuk mencapai hasil yang diharapkan.

2. Harapan (expectancy)

Harapan (expectancy) adalah suatu kesempatan yang diberikan terjadi karena perilaku untuk tercapainya tujuan. Harapan adalah peluang yang diperkirakan seseorang bahwa kegiatan yang akan dilakukannya dapat mencapai hasil yang diinginkan. Artinya, seseorang akan termotivasi apabila ia menilai pekerjaan yang akan dilakukan memiliki peluang untuk dapat memberikan sesuatu yang bermanfaat baginya. Harapan dalam konteks penelitian ini diwujudkan dalam bentuk pemberian kesempatan untuk maju agar seseorang yang bersangkutan dapat bekerja sebagaimana mestinya.

3. Insentif (incentive)

Insentif (incentive) yaitu merangsang bawahan dengan memberikan hadiah ( imbalan) kepada mereka yang berprestasi diatas standar. Dengan demikian semangat kerja bawahan akan meningkat karena umumnya manusia senang menerima yang baikbaik saja. Insentif merupakan imbalan yang didapat oleh seseorang sebagai balas jasa dari hasil pekerjaan yang telah dilaksanakannya. Apabila seseorang menilai bahwa imbalan tersebut sesuai dengan beban kerja dan tanggung jawab yang telah dilakukannya 
maka ia akan semakin atusias dalam bekerja. Bentuk insentif bisa berbentuk materi dan juga non materi. Insentif dalam konteks penilaian ini diwujudkan dalam bentuk pemberian uang tunai sebagai akibat adanya produktivitas kerja lebih.

Teori tersebut juga mendapatkan dukungan penguatan dari teori yang dikemukakan oleh Teori Mc. Clelland dalam Sihotang (2007) bahwa pegawai mempunyai cadangan energy potensial. Bagaimana energy dilepaskan dan diguanakan tergantung pada kekuatan dorongan motivasi seseorang dan situasi serta peluang yang tersedia. Energi dimanfaatkan oleh pegawai karena didorong oleh motif, harapan dan insentif. Motif adalah suatu perangsang keinginan (want) dan daya penggerak kemauan bekerja seseorang. Setiap motif mempunyai tujuan tertentu yang ingin dicapai. Harapan (expectancy) adalah suatu kesempatan yang diberikan terjadi karena perilaku untuk tercapainnya tujuan. Insentif ( incentive) yaitu memotivasi (merangsang) bawahan dengan memberikan hadiah (imbalan) kepada mereka yang berprestasi diatas prestasi standar. Dengan demikian semangat kerja bawahan akan meningkat karena umumnya manusia senang menerima yang baik-baik saja.

\section{Konsep Kinerja}

Mankunegara (2009:67) mengemukakan bahwa istilah kinerja berasal dari kata job performance atau actual performance ( prestasi kerja atau prestasi sesungguhnya yang dicapai oleh seseorang). Pengertian kinerja atau prestasi kerja adalah hasil kerja secara kualitas dan kuantitas yang dicapai oleh seorang pegawai dalam melaksanakan tugasnya sesuai dengan tanggung jawab yang diberikan kepadanya.

Poewadarminta (2006:67) mengatakan bahwa kinerja adalah prestasi yang diperlihatkan atau kemampuan kerja. Winardi (2001:282) mengemukakan bahwa kinerja adalah kemampuan kerja seorang karyawan/pegawai dalam menyelesaikan tugas yang dibebankan kepadanya secara berhasil dan berdaya guna.

Mitrani (2002:109) mengemukakan bahwa kinerja adalah seperangkat proses untuk menciptakan pemahaman bersama mengenai apa yang harus dicapai dan bagaimana mencapainya. Dharma ( 2005:1) mengemukakan bahwa kinerja adalah sesuatu yang dikerjakan atau produk jasa-jasa yang diberikan atau yang dihasilkan oleh seseorang atau sekelompok orang. Dengan demikian dapat disimpulkan bahwa kinerja adalah prestasi atau kemampuan kerja seorang karyawan atau pegawai dalam mencapai tujuan organisasi.

Harsuko (2011:50) mengidentifikasikan kinerja adalah unsur pencatatan hasil kerja SDM dan perbaikan apa yang harus dilakukan agar dimasa mendatang lebih baik. Handoko (2003) mengemukakan bahwa penilaian kinerja adalah proses dimana organisasi-organisasi mengevaluasi atau menilai prestasi pegawainya. Kegiatan ini dapat dipengaruhi keputusan-keputusan personalia dan memberikan umpan balik kepada para karyawan tentang pelaksanaan kerja mereka. Adapun kegunaan penilaian kinerja adalah sebagai berikut :

1. Mendorong orang ataupun karyawan agar berperilaku positif atau memperbaiki tindakan mereka yang dibawah standar.

2. Sebagai bahan penilaian bagi manajemen apakah karyawan tersebut telah bekerja dengan baik.

3. Memberikan dasar yang kuat bagi pembuatan kebijakan peningkatan organisasi. 
Email : megaaktiva@febi.umkendari.ac.id

Website : https://megaaktiva.umkendari.ac.id/index.php/Jurnal

\section{Indikator Kinerja}

Instrumen pengukuran kinerja Pegawai Negeri Sipil menurut Sedarmayanti (2011), adalah merupakan alat yang dipakai untuk mengukur kinerja individu seorang pegawai yang meliputi :

1. Prestasi Kerja; merupakan hasil kerja pegawai dalam menjalankan tugas, baik secara kualitas maupun kuantitas kerja.

2. Keahlian; merupakan tingkat kemampuan teknis yang dimiliki oleh pegawai dalam menjalankan tugas yang dibebankan kepadanya. Keahlian ini bisa dalam bentuk kerja sama, komunikasi, inisiatif dan lain-lain.

3. Perilaku; merupakn sikap dan tingkah laku pegawai yang melekat pada dirinya dan dibawa dalam melaksanakan tugas-tugasnya. Pengertian perilaku juga disini mencakup kejujuran, tanggung jawab, dan disiplin.

4. Kepemimpinan; merupakan aspek kemampuan manajerial dan seni dalam memberikan pengaruh kepada orang lain untuk mengkoordinasikan pekerjaan secara tepat dan cepat, termaksud pengambilan keputusan dan penentuan prioritas.

\section{Hipotesis}

Berdasarkan konsep dan hasil-hasil penelitian maka hipotesis dalam penelitian ini adalah Motivasi Kerja berpengaruh signifikan terhadap kinerja pegawai pada kantor Badan Penelitian dan Pengembangan Provinsi Sulawesi Tenggara.

\section{METODE PENELITIAN}

Adapun populasi dalam penelitian ini adalah seluruh Pegawai Kantor Badan Penelitian dan Pengembangan Provinsi Sulawesi Tenggara yang berjumlah sebanyak 53 orang. Penentuan sampel dalam penelitian ini menggunakan metode sensus/ total sampling/sampling jenuh yaitu mengambil seluruh anggota populasi menjadi responden yakni 53 orang sampel responden. Untuk menjawab permasalahan dan Hipotesis dalam peneliian ini, maka digunakan analisis sebagai berikut :

1. Analisis deskriptif yaitu metode penganalisisan data yang mengumpulkan, mengklasifikasiakan, menganalisa, dan menginterpretasikan data sehingga memberi gambaran menyeluruh mengenai masalah yang dihadapi Sugiyono (2007:110)

2. Alat Analisis yang digunakan adalah regresi linear sederhana Sugiyono (2012:188) dengan model:

Dimana:

$$
\mathbf{Y}=\mathbf{a}+\mathbf{b X}
$$

$\mathrm{Y}=$ Variabel Terkait

$\mathrm{X}=$ Variabel Bebas

$\mathrm{a}=$ Nilai Konstanta

$\mathrm{b}=$ Koefisien Regresi

Aplikasi model tersebut selanjutnya dikondisikan dengan penelitian ini sehingga diperoleh persamaan regresi linear sederhana dalam bentuk aplikatif sebagai berikut :

$$
\mathbf{Y}=\mathbf{a}+\mathbf{b X}+\mathbf{e}
$$

Dimana:

$\mathrm{Y} \quad=$ Variabel Kinerja Pegawai

$\mathrm{X} \quad=$ Variabel Motivasi

a $\quad=$ Nilai Konstanta 


\section{JURNAL MEGA AKTIVA}

Email : megaaktiva@febi.umkendari.ac.id

Website : https://megaaktiva.umkendari.ac.id/index.php/Jurnal

\section{$\mathrm{b}=$ Koefisien regresi \\ e $\quad=$ faktor kesalahan}

Agar tidak menimbulkan kesalahan penafsiran terhadap variabel yang dibahas dalam penelitian ini, maka diberikan definisi operasional variabel sebagai berikut:

1. Motivasi Kerja $(\mathrm{X})$ adalah dorongan yang timbul dari dalam pegawai Badan Penelitian dan Pengembangan Provinsi Sulawesi Tenggara untuk bekerja dengan baik yang diamati dari indikator : motif, harapan dan insentif.

a. Motif (motif) adalah tanggapan responden terhadap keinginannya untuk bekerja secara maksimal dalam rangka mencapai hasil yang diharapkan. Indikator motif diukur dari tiga item indikator yaitu : (1) meningkatkan keinginan diri untuk bekerja dengan baik, (2) mengendalikan diri agar bekerja secara optimal, serta (3) mengarahkan diri untuk produktif dalam bekerja.

b. Harapan (expectancy) adalah tanggapan responden terhadap keinginan untuk memperoleh kesempatan untuk maju agar pegawai yang bersangkutan dapat bekerja secara maksimal. Indikator harapan diukur dari tiga item indikator yaitu : (1) daya gerak, (2) kesempatan, (3) peluang.

c. Insebtif (incentive) yaitu tanggapan responden terhadap pemberian balas jasa finansial sebagai akibat adanya prestasi kerja yang dihasilkan. Indikator insentif diukur dari tiga item indikator yaitu : (1) bonus/uang tunai, (2) rangsangan/perilaku, (3) penghargaan/sertifikat.

2. Kinerja pegawai (Y) adalah kemampuan kerja pegawai Badan Penelitian dan Pengembangan Provinsi Sulawesi Tenggara yang di amati melalui indikator Prestasi karja, Keahlian, perilaku, Kepemimpinan.

a. Prestasi kerja merupakan hasil kerja pegawai dalam menjalankan tugas baik secara kualitas maupun kuantitas kerja.

b. Keahlian merupakan tingkat kemampuan teknis yang dimiliki oleh pegawai dalam menjalankan tugas yang dibebankan kepadanya. Keahlian ini bisa dalam bentuk kerja sama, komunikasi, inisiatif dan lain-lain.

c. Perilaku merupakan sikap dan tingkah laku pegawai yang melekat pada dirinya dan dibawa dalam melaksanakan tugas-tugasnya. Pengertian perilaku dapat mencakup kejujuran, tanggung jawab, dan disiplin.

d. Kepemimpinan merupakan aspek kemampuan manajerial dan seni dalam memberikan pengaruh kepada orang lain untuk mengkoordinasikan pekerjaan secara tepat dan tepat, termaksud pengambilan keputusan dan penentuan prioritas.

\section{HASIL DAN PEMBAHASAN}

Analisis hasil penelitian mengenai pengaruh motivasi kerja dan kinerja pegawai, yang dianalisis dengan menggunakan metode kualitatif dan kuantitatif. Analisis kualitatif digunakan untuk membuktikan hipotesis yang di ajukan dengan menggunakan model analisis regresi linear sederhana, sedangkan analisis kuantitatif digunakan untuk menelaah pembuktian analisis kualitatif. Pembuktian ini dimaksudkan untuk menguji variasi suatu model regresi yang digunakan dalam menerangkan variabel bebas (X) terhadap variabel terikat (Y) dengan cara menguji kemaknaan dari koefisien regresinya. Adapun hasil analisis regresi linear sederhana dengan menggunakan Program SPSS versi 16,0 dapat dirangkum melaului tabel sebagi berikut: 


\section{JURNAL MEGA AKTIVA}

Email : megaaktiva@febi.umkendari.ac.id

Website : https://megaaktiva.umkendari.ac.id/index.php/Jurnal

Tabel 1. Hasil Analisis Regresi Linear Sederhana

\begin{tabular}{lcccc}
\hline \multicolumn{1}{c}{ Variabel } & $\begin{array}{c}\text { Koefisien Regresi } \\
(\mathbf{b})\end{array}$ & $\mathbf{t}_{\text {hitung }}$ & $\mathbf{t}_{\text {signifikan }}$ & Keterangan \\
\hline Motivasi Kerja (X) & 0,941 & 19.848 & 0,000 & Signifikan \\
\hline Konstan (a) & $: 2.564$ & & & $\alpha=0,05$ \\
Koefisien korelasi $(\mathrm{r})$ & $: 0,941$ & & $\mathrm{t}_{\text {tabel }}=1,674$ \\
Koefisien Determinasi $\left(\mathrm{r}^{2}\right)$ & $: 0,885$ & & \\
Error & 0,41019 & & & \\
\hline
\end{tabular}

Sumber : Rekapitulasih Hasil Analisis Regresi (Data Primer di Olah, (2016)

Berdasarkan Tabel 1 dapat diketahui persamaan regresi linear sederhana sebagai berikut :

$$
\mathrm{Y}=2.564+0,941 \mathrm{X}
$$

Model persamaan regresi dapat yang dapat dituliskan dari hasil diatas dalam bentuk persamaan regresi adalah sebagai berikut:

1. Koefisien Regresi (b)

Sesuai hasil penelitian diketahui nilai koefisien regresi (b) variabel motivasi kerja (X) sebesar 0,941 memberikan arti bahwa motivasi kerja berpengaruh positif terhadap kinerja pegawai (Y). Hal ini menunjukan bahwa dengan penambahan motivasi kerja, maka akan terjadi peningkatan kinerja pegawai sebesar 0,941 dan begitu pun sebaliknya.

2. Koefisien Korelasi ( $\mathrm{r}$ )

Sesuai hasil analisis dengan menggunakan SPSS versi 16,0 dapat diketahui nilai koefisien korelasi ( $\mathrm{r}$ ) yang diperoleh sebesar 0,941 atau mempunyai hubungan yang sangat kuat karena mendekati nilai angka satu.

3. Koefisien Determinasi $\left(\mathrm{r}^{2}\right)$

Berdasarkan hasil analisis regresi linear sederhana diperoleh nilai koefisien determinasi $\left(r^{2}\right)$ sebesar 0,885 . Hal ini menunjukan bahwa variasi perubahan kinerja pegawai dipengaruhi oleh motivasi kerja sebesar 0,885 atau $88,50 \%$, dan selebihnya 0,115 atau $11,50 \%$ ditentukan oleh faktor lain diluar model penelitian ini. Sehingga dapat disimpulkan bahwa pengaruh variabel motivasi kerja terhadap kinerja pengarunya sangat berarti.

4. Hasil Uji Parsial (Uji t)

Uji t dilakukan untuk mengetahui pengaruh secara parsial variabel bebas (Motivasi Kerja) terhadap variabel terikat (Kinerja Pegawai). Hasil pengujian parsial (Uji t) antara variabel motivasi kerja $(\mathrm{X})$ terhadap variabel kinerja pegawai $(\mathrm{Y})$ menunjukan nilai thitung $=19,848>t_{\text {tabel }}=1,674$ dengan nilai signifikan sebesar $t_{\text {sig }}=0,000$ yang berarti lebih kecil dari nilai $\alpha=0,05$. Dengan demikian motivasi kerja $(\mathrm{X})$ secara parsial berpengaruh signifikan terhadap kinertja pegawai, dan hipotesis yang di ajukan dapat diterima.

\section{Pembahasan}

Berdasarkan hasil Penelitian dan hasil analisis data , bahwa variabel motivasi kerja (X) memberikan pengaruh yang signifikan terhadap kinerja pegawai (Y) pada kantor Badan Penelitian dan Pengembangan Provinsi Sulawesi Tenggara. Hal ini dapat dilihat dari nilai koefisien determinasi $\left(\mathrm{r}^{2}\right)$ yang diperoleh sebesar 0,885 . Selain itu pula dapat dilihat dari hasil koefisien korelasi (r) untuk melihat seberapa kuat hubungan antara 
motivasi kerja terhadap kinerja pegawai pada kantor badan penelitian dan pengembangan Provinsi Sulawesi Tenggara.

Hasil analisis regresi sederhana menunjukan bahwa variabel motivasi kerja yakni motif pegawai mempunyai pengaruh yang positif dan signifikan terhadap kinerja pegawai. Hal ini di artikan bahwa apabila ada keinginan untuk bekerja dengan baik maka akan menghasilkan kinerja yang baik. Maksudnya Pegawai pada kantor Badan Penelitian dan Pengembangan Provinsi Sulawesi Tenggara sudah memiliki keinginan untuk meningkatkan kualitas kerja mereka, sehingga kinerja para pegawai pada kantor Badan Penelitian dan Pengembangan Provinsi Sulawesi Tenggara bisa dikatan baik.

Hasil analisis regresi sederhana menunjukan bahwa variabel motivasi kerja yakni harapan pegawai mempunyai pengaruh yang positif dan signifikan terhadap kinerja pegawai. Hal ini dapat di artikan bahwa setiap pegawai memiliki harapan yang baik untuk meningkatkan kinerja, semakin tinggi harapan maka akan semakin tinggi pula kinerja yang akan di capai. Dengan kata lain pegawai pada kantor Badan Penelitian dan Pengembangan Provinsi Sulawesi Tenggara memiliki harapan yang besar dimana para pegawai ingin menghasilkan hasill kerja yang maksimal dalam rangka pencapaian tujuan yang diharapkan.

Hasil Analisis regresi sederhana menunjukan bahwa variabel motivasi kerja yakni Insetif yang diberikan pada pegawai mempunyai pengaruh yang positif dan signifikan terhadap kinerja pegawai. Hal ini dapat di artikan bahwa pegawai yang memiliki kinerja baik akan diberikan insentif atau bonus dari atasan sesuai prestasi yang dihasilkan oleh pegawai. Maksud dari insentif yaitu pegawai pada kantor Badan Penelitian dan Pengembangan Provinsi Sulawesi Tenggara sudah bekerja dengan baik sesuai dengan harapan pimpinan, sehingga pimpinan memberikan bonus kepada setiap pegawainya yang memiliki prestasi kerja.

Hasil Penelitian ini mendukung penelitian terdahulu yang dilakukan oleh Anwar Prabu ( 2005) dengan judul pengaruh " Motivasi Terhadap Kinerja Pegawai Badan Koordinasi Keluarga Berencana Nasional Kabupaten Muara Enim” yang menyatakan bahwa variable motivasi berpengaruh terhadap kinerja pegawai Badan Koordinasi Keluarga Berencana Nasional Kabupaten Muara Enim.

Penelitian yang sejalan dengan penelian ini yaitu penelitian yang dilakukan oleh Ramli E (2008) dengan judul pengaruh Motivasi Kerja dan Disiplin Kerja Terhadap Kinerja Pegawai Sekretariat DPRD Kabupaten Pelalawan. Hasil penelitian menunjukan bahwa hasil perhitungan secara statistic didapatkan bahwa variabel motivasi kerja kerja memberikan pengaruh signifikan terhadap kinerja pegawai sekretariat DPRD Kabupaten Pelalawan.

Berdasarkan uraian dan pembahasan diatas dapat diketahui bahwa motivasi kerja berpengaruh signifikan terhadap kinerja pegawai pada kantor badan penelitian dan pengembangan Provinsi Sulawesi Tenggara. Artinya perubahan motivasi kerja kearah yang lebih baik melalui perilaku motif, harapan, serta insentif dapat meningkatkan kinerja pegawai apabila diamati melalui indikator prestasi kerja, keahlian, perilaku dan kepemimpinan. 


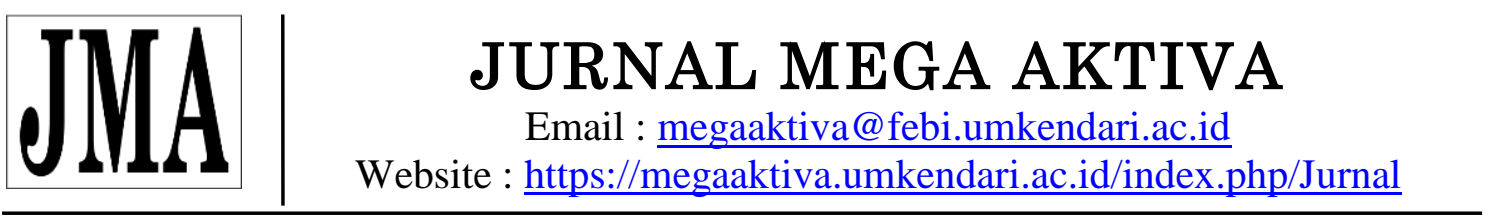

\section{KESIMPULAN}

Berdasarkan hasil analisis dan pembahasan yang terkait rumusan masalah dan hipotesis dapat disimpulkan bahwa motivasi kerja yang diukur melalui indikator motif, harapan dan insentif, berpengaruh positif dan signifikan terhadap kinerja pegawai pada kantor badan penelitian dan pengembangan Provinsi Sulawesi Tenggara, yang diukur dengan indikator prestasi kerja, keahlian, perilaku dan kepemimpinan. Besarnya pengaruh motivasi kerja terhadap kinerja pegawai dapat dilihat dari nilai koefisien determinasi $\left(\mathrm{r}^{2}\right)=0,885$ atau $88,50 \%$ yang berarti bahwa kinerja pegawai pada kantor Badan Penelitian dan Pengembamgan Provinsi Sulawesi Tenggara 88,50\% ditentukan oleh motivasi kerja dan sisanya $11,50 \%$ ditentukan oleh variabel lain.

\section{DAFTAR PUSTAKA}

Anwar Prabu, 2005. Pengaruh “ Motivasi Terhadap Kinerja Pegawai Badan Koordinasi Keluarga Berencana Nasional Kabupaten Muara Enim”. Jurnal Manajemen \& Bisnis Sriwijaya, Vol.3 No. 6 Desember, 2005

Arikunto, Suharsimi 2006, Prosedur Penelitian Suatu Pendekatan Praktek, Rinneka Cipta, Jakarta

BernardinH Jhon and Joyce E. A. Russell, 2002. Human Resource Management: An Experiential Approach, McGraw-Hill Inc

Dharma, Agus, 2005, Manajemen Prestasi Kerja, Ghalia Indonesia, Jakarta

Ghozali, Imam.2005. Aplikasi Analisis Multivariate dengan Program SPSS. Semarang: Badan Penerbit Universitas Diponegoro

Gibson, 1996. Organisasi dan Manajemen, (Terj. Djorban Wahid), Erlangga, Jakarta

Handoko, Hani T, 2003, Pengeruh Upah Terhadap Motivasi Kerja Karyawan, UGM. Press., Yogyakarta

Handayaningrat, Soewarno, 1997. Pengantar Studi Administrasi dan Manajemen, Gunung Agung, Jakarta

Hasibuan, S.P. Melayu, 2009, Organisasi dan Motivasi, PT. Bumi Aksara, Jakarta

Hidayat, 2001, Peningkatan Produktivitas Organisasi Pemerintah, Prisma, Jakarta Ishak dan Hendri Tanjung(2003) Manajemen Motivasi. Jakarta PT.Grasindo Kamaruddin, Kohar, 2001, Manajemen Tenaga Kerja. Aksara Baru, Jakarta Maris, Masri, 2007, Manajemen Sumber Daya Manusia. Media Asri, Jakarta

Mangkunegara, Anwar Prabu, 2009, Manajemen Sumber Daya Manusia.perusahaan Bandung: Remaja Rosdakarya

Mitrani, Alain. 2002. Manajemen Sumber Daya Manusia Berdasarkan Kompetensi. PT. Pustaka Utama Grafiti. Jakarta

Pace, Wayne R dan Don F. Faules, 2003, Komunikasi Organisasi, Strategi Meningkatkan Kinerja Organisasi. Terjemahan Deddy Mulyana, PT. Remaja Rosdakarya, Bandung Ramli. E, 2008, Pengaruh Motivasi Kerja dan Disiplin Kerja Terhadap Kinerja Pegawai Sekretariat DPRD Kabupaten Pelalawan, Tesis, Universitas Brawijaya, Malang Riduwan. 2004. Metode dan Teknik Menyusun Skripsi dan Tesis. Alfabeta Bandung

Robbins, P. Stephen, 2001, Pemimpin dan Kepemimpinan, Terjemahan Mar'at, Ghalia Indonesia, Jakarta 2008. Perilaku organisasi. PT. Indeks Kelompok Gramedia 


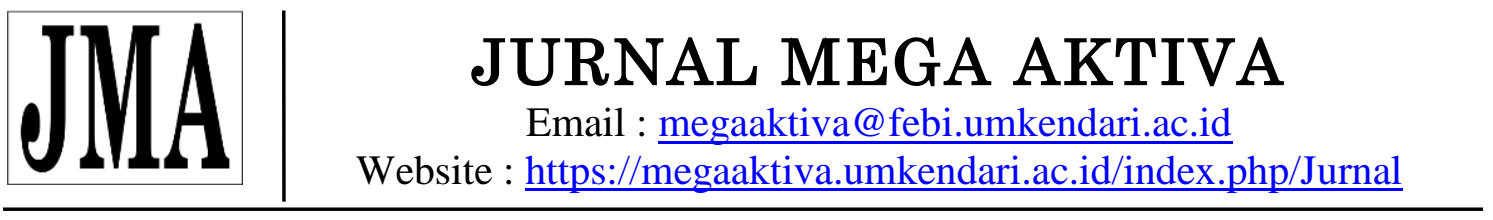

Ruky Achmad S.,2002, Sistem Manajemen Kinerja. Di Download dari : http//www.geocitios.com

Samir, Sofyan, 2003. Motivasi Pegawai dan Pendekatan Manusiawi, Rineka Cipta, Jakarta

Sedarmayanti,2011. Manajemen sumber dayamanusia; Reformasi Birokrasi dan manajemen pegawai negeri sipil, PT. Refika aditama, Bandung.

Setyadi, Iwan, 2003, Memperkenalkan Manajemen Personalia dalam Praktek, Rineka Cipta, Jakarta

Setiawan, Abi, 2000, Pokok-pokok Organisasi dan Manajemen, Ghalia Indonesia, Jakarta Siagian, SP, 1999. Filsafat Administrasi, PT. HJ Masagung, Jakarta.

Susilo, Sarwoto,2001. Membangun Motivasi Kerja, Media Asri,Jakarta

Supranto, J. 1997. Metode Riset Bisnis.Yogyakarta: CV . Andi Offset

Suprianto,2002. Pengaruh Motivasi Terhadap Prestasi Kerja Karyawan Bagian Produksi Pada PT. BARABAS, Skripsi Universitas Brawijaya, malang

Sugiyono, 2007, Statistik Untuk Penelitian. Alfabeta Bandung.

Sugiyono, 2012. Metode penelitian kuantitatif kualitatif Dan $R \& D$. Bandung : CV. Alfabeta.

Syamsi, Abdullah, 2003, Faktor-faktor yang Mempengaruhi Produktivitas Karyawan, Unhas Press, Ujung Pandang

Winardi P, 2002; Motivasi dan Pemotivasian dalam manajemen. Cetakan kedua Jakarta: PT. Raja Grafindo Persada 2001, Manajemen Perkantoran dan Pengawasan, Alumni, Bandung 